How social security policies and

\section{economic}

transformation

affect poverty and

inequality: Lessons

for South Africa

\section{Marianne Ulriksen}

University of Johannesburg

Conference paper presented at 'Overcoming inequality and structural poverty in South

Africa: Towards inclusive growth and development', Johannesburg, 20-22

September 2010

\section{OVERCOMING INEQUALITY AND STRUCTURAL} PO

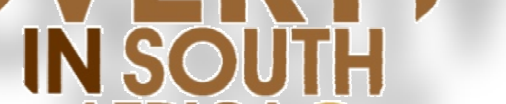

AFRICA
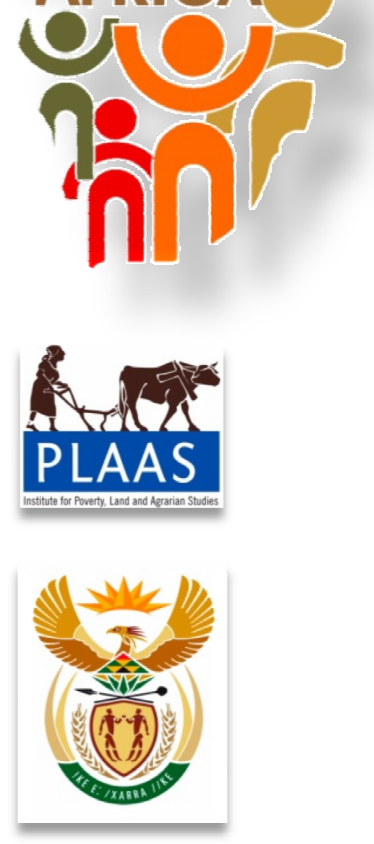

圈.

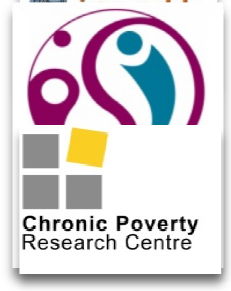




\title{
How social security policies and economic transformation affect poverty and inequality: Lessons for South Africa
}

Marianne Ulriksen

\begin{abstract}
:
This article examines how various characteristics of social and economic policy frameworks affect poverty and inequality levels in developing countries, principally in Botswana and Mauritius. The research findings suggest that poverty and inequality are lower in countries with generous and broad-based - rather than pro-poor - social security policies, and where social policies are complemented by economic policies promoting economic transformation more so than merely economic growth. While South Africa's challenges of combating poverty and inequality are shaped by its own historical context, the lessons from other countries offer the opportunity to reflect on the social consequences of various social and economic policy mixtures. Particularly, it may be worth considering how to bridge the divide between the economically productive contributors to social security policies and the economically marginalised beneficiaries of such policies.
\end{abstract}

Keywords: social protection; economic transformation; poverty reduction; inequality 


\section{Introduction}

The dominant focus of the World Bank, IMF and much of the aid industry, supported by the MDG approach of the UN was focused only on the poorest of the poor working with the erroneous assumption that the question of poverty could be solved without addressing issue[s] of equity, social inclusion and the role of the state in fostering a developmental project for the benefit of all social groups (Deacon, 2010).

How best to combat poverty and reduce structural inequality in Africa is, and has been for decades, a dominant focus of international aid agencies, local governments, academia, and civil society alike. Remarkably, there appear to now be a near-hegemonic position amongst most of these actors that social protection is a preferred policy for addressing issues of poverty (Adesina, 2010). The World Bank and IMF acknowledge that markets are not perfect and that social safety nets targeted at the most vulnerable are necessary to avoid human disasters (World Bank, 2001). The UN along with many other donor agencies promote the social protection floor advocating that minimum cash benefits to the poor is a useful strategy for poverty reduction (ILO \& WHO, 2009; Hickey et al., 2008).

Worthy as these initiatives are, there may be a concern that this sole focus on the poor fails to address structural inequalities and instead reinforces a divide between the poor and the nonpoor. Moreover, despite some lip-service to the contrary, the promotion of social protection is still merely a by-side to the economic growth agenda. Questions of how social and economic policies may mutually strengthen developmental efforts towards broad-based economic transformation deserve more scrutiny than is currently the case.

The object of this paper is to examine how contrasting mixtures of social and economic policies have affected poverty and inequality levels in developing countries; this with lessons for South Africa in mind. A central premise of the initial theoretical discussion is how policies of social welfare and economic development can ensure that the poor become part of the developmental efforts rather than distinct from it. The empirical section starts with a statistical analysis of developing countries which examine the effects of social protection policies and economic modernisation (as an alternative to economic growth) on poverty levels. The findings of this analysis are complemented by examinations of Botswana and Mauritius; now considering how different combinations of social and economic strategies impact on poverty and inequality. Potential lessons from the analyses are then reflected against the case of South Africa.

\section{Social protection and economic transformation: The theoretical debate}

The dominating approach to economic and human development for the last decade or two has been the pro-poor growth strategy promoted by the World Bank. At its core this strategy seeks to achieve sustained and rapid economic growth benefiting also the poor through sound economic policies, political stability and investments in physical and human capital. Social safety nets supplement this strategy by targeting those poor and vulnerable groups unable to benefit from the economic growth (Besley \& Cord, 2007).

Critics argue that the safety nets component promoted by the World Bank and IMF is a very narrow definition of social protection. Moreover, as there is a tendency to focus mainly on food-forwork and cash-for-work programmes many of these safety nets fail to address the plight of destitute people who are unable to work (Ellies et al., 2009). Certainly, relief work programmes appear a favourable strategy, even though cash and food transfers for non-working vulnerable groups (elderly, children etc.) are also acknowledged as important elements of poverty relief (Ravallion, 2008). As such, the World Bank is coming closer to the idea of social protection promoted by UN and others. Social protection in a broader sense may be described as 'all public and private initiatives that provide income or consumption transfers to all poor, protect the vulnerable against livelihood risks, and enhance the social status and rights of the marginalised' (Ellis et al., 2009:8). Social protection is then a variety of targeted transfers (cash, food, inputs or assets), where the focus is to secure the basic needs and empowerment of the poor, vulnerable, and marginalised.

While social services such as promotion of education and health are acceptable parts of the pro-poor agenda, social safety nets are still regarded as secondary to economic goals and are generally suggested to be kept at a minimum (Mkandawire, 2004). Proponents of the broader 
understanding of social protection, on the other hand, often fail to integrate the role of economic policies. They suggest that social protection assists in providing a skilled and healthy work force and is important in creating opportunities for the poor. Nevertheless, they seem to accept the dominant growth strategies (Adesina, 2010, Norton et al., 2002) and then concentrate on how best to develop, target and implement social protection policies (Ellis et al., 2009). There has thus been a tendency to focus on economic growth and, as an add-on, social protection for the poorest of the poor; questions regarding social protection - termed here as social security policies - for the broader population and economic transformation to create meaningful employment and social equity have been neglected.

It seems obvious that social policies aimed at reducing poverty should focus on the poor. However, such strategies not only go against the historical evidence of Western welfare states (Deacon, 2010), they also carry the risk of creating a divide between the poor and the non-poor that may be arduous to overcome with detrimental consequences for poverty and inequality in the long term. Let me elaborate on this possibly contentious argument by considering first the role of social security policies in reducing poverty and inequality, and then how social outcomes may equally be improved when a mix of social and economic policies foster structural economic transformation.

Various policies ensuring social protection - be they social cash transfers, insurance schemes, benefits in kind etc. - may be defined along two dimensions: how generous they are and which social groups they cover (Bonoli, 1997). We know from research on Western welfare states that countries with a mix of social security policies covering broadly across income groups tend to have more generous social policies and consequently higher levels of social well-being - or in reverse: that 'the more we target benefits at the poor only [...] the less likely we are to reduce poverty and inequality' (Korpi \& Palme, 1998:681).

This may seem counter-intuitive. However, the reason for differences in the character of social security policies across countries lies in the interests and commitments of the non-poor, particularly the middle-class (Esping-Andersen, 1990). This heterogeneous group between the rich and lower-income groups play essential roles in promoting economic developments and good governance as they are generally resourceful and largely politically independent of the state - unlike the rich in many developing countries (Birdsall, 2010). They also have interests in adequately funded social services and social protection (Ibid.), though they can ensure social welfare through both private and public institutions. Essentially, countries with social security policies catered solely for the poor do badly with regard to poverty and inequality as the non-poor do not benefit from such social policies and therefore are less willing to contribute to covering the costs. Hence, political feedbacks often cause social security to become more targeted, efficient and mean. Conversely, when also non-poor benefit, social policies tend to be more generous causing a more effective redistribution (Gelback \& Pritchett, 2000). Basically, by targeting only the poor there is a risk of isolating this group outside the mainstream economy; the non-poor (which in developing countries may also include better-off lower-income groups in formal employment) may have charitable concerns for those in destitution and some minimal social assistance may be in place, but little else push the non-poor to pursue expansion of social policies from which they are unlikely to benefit.

The contention here is not that Western countries can provide developing countries with blueprints of social protection. However, it is surprising and potentially misleading, that international agencies have made suggestions contrary to historical evidence (UNRISD, 2010). Poverty, and more so inequality, has most efficiently been reduced in countries where social welfare has been a national project rather than a pro-poor one, and as our second topic, where social and economic policies are aimed at economic transformation and employment creation.

The argument in favour of social protection is that transfers will assist the poor to increase their capabilities - empower them - so they can also benefit from economic opportunities. Research shows that cash transfers improve the livelihoods of the poor, enable them to pursue less hazardous behaviours, and enhance their skills (Samson, 2009). Arguably also, such transfers support, rather than hamper, economic growth (Cichon \& Scholz, 2009). Yet important assumptions carry this strategy. For instance, World Bank researcher, Martin Ravallion, argues that relief work programmes are important safety nets where the needy can sign up, especially during periods of crisis, to work for a 'not too high' wage rate. The advantage is that 'when the crisis is over, the safety net will no 
longer be needed for the majority of workers and [..] they will automatically return to regular work' (2008:19). Well, that requires availability of jobs. While relief work programmes set a condition on receiving benefits, cash transfers - even if for non-working groups such as children or pensioners have the advantage of freeing the direct or indirect beneficiary to seek jobs and/or improve skills. Once again, however, this is only useful if there are opportunities to engage meaningfully in the economy.

Undoubtedly, one of the best ways out of poverty is to get decent employment - to be a productive part of the economy and thereby contributing directly to economic development and indirectly, for instance through taxation, to social policies from which one may benefit in times of need. There is probably consensus on that. However, whether the state is able to - or should create employment opportunities, and how, is highly controversial. And there are no easy solutions. One way, is to consider whether the poor become integrated parts of the economy rather than distinct from it. For instance, to promote relief work or subsistence agriculture does not necessarily make beneficiaries a contributory part of the economy and they are therefore likely to stay in a position of economic insecurity, also because their incomes, when occurring, are usually minimal. Equally, cash transfers which are not complemented by strategies to ensure that beneficiaries will (or had in the past) contribute(d) to economic development and public expenditure, may cause beneficiaries to lose a sense of obligation which is essential to ensure continued long-term support for generous, but costly, social policies.

To recapitulate: it is laudable to promote cash transfers to the poor, but if such policies are not complemented by strategies of economic transformation and employment creation it is hard to see how such policies will be sustained and how structural inequalities can be overcome. Cash transfers may improve the well-being of the poor. However, by definition, beneficiaries of meanstested policies will still be poor and distinct from the salaried and better-off population, unless the composition of economic growth is such that it offers decent employment opportunities. I am not downgrading the importance of economic growth - that is a necessary condition - but perhaps (difficult) changes to the structures of a country's economy are just as important? And perhaps social security needs from the beginning to be a national project - ensuring that the majority benefits, but also contributes? The following empirical analyses attempt in tackling these questions.

\section{The effects of social policies and economic modernisation on poverty levels}

This section offers a statistical analysis which first tests the relation between social policies and poverty and, second, examines the extent to which economic modernisation, as an alternative to economic growth, affect poverty. The statistical analysis is rudimentary in that it focuses merely on causes to poverty, cannot suggest how social and economic strategies may be linked or give any indications of the forms that economic transformation may take. The case studies of Botswana and Mauritius give us the opportunity to elaborate on the linkages between social security policies and economic transformation and the effects on poverty and inequality.

Poverty is generally considered to be a multi-dimensional concept. That is, being poor is not only about lack of income but also about being short of other basic commodities such as food, water, knowledge, and health facilities (Barrientos, 2010). Of the poverty statistics available, the Human Poverty Index (HPI) best captures this broader understanding of poverty. HPI measures the proportion of people below a threshold level in basic dimensions of human development - i.e. health, knowledge, and standard of living. More details about the poverty variable and other variables can be found in the Appendix 1.

Theoretically we assumed that social security policies that are both generous and cover broadly best reduce poverty. To test this hypothesis we first correlate social policy expenditures (as percentage of GDP) with HPI. As evident in Table 1 there is a strong correlation between social policy expenditures and poverty such that higher expenditures lead to lower poverty rates. This is consistent with findings by Barrientos (2010) who tests the relations between social policy expenditures and measures for income poverty. However, the adjusted R square in Table 1 is higher than Barrientos' findings which indicate that social policy expenditures account for greater variation when one using a broader measure for poverty. 
Table 1: Social policies and poverty

\begin{tabular}{lccc}
\hline Dependent variable & \multicolumn{3}{c}{ Human poverty index (HPI) } \\
\hline \hline Independent variable & $\begin{array}{c}\text { Social } \\
\text { expenditure }\end{array}$ & $\begin{array}{c}\text { Social } \\
\text { coverage }\end{array}$ & $\begin{array}{c}\text { Social security } \\
\text { policies }\end{array}$ \\
\hline \hline Coefficient & -.865 & -.784 & -.586 \\
(Standard error) & $(.173)$ & $(.117)$ & $(.083)$ \\
& & & .477 \\
Adj. R Square & .300 & .340 & 54 \\
Number of cases & 57 & 87 & \\
\hline
\end{tabular}

Next we test the relation between social policy coverage (which measures the extent to which social policies cover across income groups) and poverty. Again, this relation is highly significant and in the right direction which means that the more social policies cover across various income groups the lower the poverty levels. Most importantly, however, when we combine social expenditures and social coverage (into social security policies) the impact is the strongest. Thus, for social policies to positively affect poverty levels, it is not only important to increase expenditure levels but also that social policies cover broadly.

To ensure that the relationship between social policies and poverty is robust a set of control variables are included, which cover potential institutional and socio-economic causes to poverty. As indicated in model 2 and 4 in Table 2, the effects of social policies stay significant and add to the explanatory power of the models.

Table 2: Social policies and control variables' effects on poverty (HPI)

\begin{tabular}{|c|c|c|c|c|}
\hline & Model 1 & Model 2 & Model 3 & Model 4 \\
\hline \multicolumn{5}{|l|}{ Political institutions } \\
\hline Government & 3.449 & 3.382 & $-3.404 *$ & -2.372 \\
\hline effectiveness & (2.960) & (3.172) & $(1.857)$ & (1.956) \\
\hline \multirow[t]{2}{*}{ Democracy } & -.061 & -.021 & .142 & .119 \\
\hline & $(.200)$ & $(.212)$ & $(.171)$ & $(.182)$ \\
\hline \multicolumn{5}{|l|}{ Socio-economic factors } \\
\hline \multirow[t]{2}{*}{ HIV/Aids } & $.727^{* * *}$ & $.529 *$ & .413 & .343 \\
\hline & $(.210)$ & $(.302)$ & $(.255)$ & $(.246)$ \\
\hline \multirow[t]{2}{*}{ Unemployment } & -.114 & .409 & .215 & $.541 *$ \\
\hline & $(.209)$ & $(.306)$ & $(.208)$ & $(.274)$ \\
\hline \multicolumn{5}{|l|}{ Economic conditions } \\
\hline \multirow{2}{*}{ GDP per capita } & $-.003 * * *$ & $-.002 * * *$ & & \\
\hline & $(.000)$ & $(.001)$ & & \\
\hline \multirow{2}{*}{$\begin{array}{l}\text { Economic } \\
\text { modernisation }\end{array}$} & & & $-.377 * * *$ & $-.323 * * *$ \\
\hline & & & $(.051)$ & $(.069)$ \\
\hline \multicolumn{5}{|l|}{ Social policies } \\
\hline \multirow[t]{2}{*}{ Social security policies } & & $-.203^{* *}$ & & $-.151^{* *}$ \\
\hline & & $(.082)$ & & $(.066)$ \\
\hline \multirow[t]{2}{*}{ Constant } & $37.759 * * *$ & $35.490 * * *$ & $39.699 * * *$ & $39.536 * * *$ \\
\hline & $(3.607)$ & $(4.341)$ & $(3.257)$ & $(4.174)$ \\
\hline Adj. R Square & .557 & .629 & .698 & .721 \\
\hline F-test & $18.119 * * *$ & $12.892 * * *$ & $26.399 * * *$ & $16.491 * * *$ \\
\hline Number of cases & 69 & 43 & 56 & 37 \\
\hline
\end{tabular}


$* * * \mathrm{p}<.01 * * \mathrm{p}<.05 * \mathrm{p}<.10$

Results are similar when all models have $\mathrm{N}=37$

Table 2 furthermore tests the impacts of economic growth versus economic transformation on poverty levels. The theoretical argument is that while economic growth is important, it may be equally critical that development is based on some form of structural transformation of the economy. Here we use a simple proxy for structural transformation, namely economic modernisation which measures the percentage of the population not employed in agriculture. Economic modernisation is argued to be important in relation to poverty reduction as expanding manufacturing industries and service sectors give people the opportunity to partake in formal employment at reasonable salary levels, whereas high levels of occupation in farming may imply unsophisticated agricultural production, informal employment, and subsistence farming.

Model 1 and 2 confirm that economic growth (reflected as GDP per capita) is indeed important for poverty reduction. Model 3 and 4 include economic modernisation instead of GDP per capita, and it becomes apparent that economic modernisation equally has a significant effect on poverty levels and in fact improves the explanatory power of the models. This by no means disturbs the established consensus that economic growth is important for poverty reduction. However, the finding does indicate that we need to better understand how to ensure structural transformation and increased (decent) employment opportunities, rather than concentrate purely on policies of economic growth. Others also suggest that it is not merely the size of growth, but more so its composition that matters - particularly expansion of labour-intensive sectors is deemed critical (Loayza \& Raddatz, 2010).

The purpose of this analysis is merely to establish the hypothesised effects of social security policies and economic modernisation, rather than to identify all relevant causes to poverty. Yet it is curious that the extent of unemployment have little direct effect on poverty. There may be a number of reasons for this. First, being in employment is not necessarily a guarantee that one receives a decent salary. Second, if there are good social security schemes in place, unemployment need not lead to destitution. Third, it is likely that unemployment is associated with economic modernisation in that structural transformation which expands avenues of employment also increases formal unemployment. This suggests that as an economy modernises, it is critical to identify measures to tackle unemployment and support the unemployed through their (hopefully short) period of austerity.

\section{Experiences from Botswana and Mauritius}

So far we have established that broad-based and generous social security policies as well as economic modernisation reduce poverty rates across developing countries. This section concentrates on the cases of Botswana and Mauritius and demonstrates well how contradictory experiences of social policy expansion and economic development impact on poverty and inequality.

Indeed, it is striking that despite many similarities, the levels of poverty and inequality in these two countries are remarkably different. Botswana and Mauritius have both, despite pessimistic prospects at independence, developed into stable, capitalist democracies with remarkable records of economic growth and good governance. In fact, they are on similar levels of economic wealth, score alike and well on ratings of economic freedom, indexes of democracy, state capacity and transparency. Yet in Botswana more than 30\% are poor according to the Human Poverty Index compared to just over $10 \%$ in Mauritius; there are hardly any in Mauritius that live for less than 1US\$ a day in contrast to all of $23 \%$ in Botswana; and income inequality in Mauritius stand at a Gini coefficient of about 0.38 whereas this figure is well above 0.5 in Botswana (Ulriksen, 2010). In the following we consider the mix of economic and social strategies in the two countries and how these may be related to the divergent social outcomes. The focus is purely on social security policies as the role of social services, such education and health, are less disputed. It is also outside the scope of this paper to analyse why the two countries have developed vastly different social and economic policy frameworks.

\subsection{Economic growth and residual social policies in Botswana}


When Botswana achieved its independence in 1966 it was underdeveloped and entirely dependent on beef exports. Fortunes changed in the 1970s when a lucrative mineral export sector was established. While mineral resources carried high and continuous economic growth and enabled the government to expand infrastructure and social services, social security policies have been a residual part of the developmental strategies - generally reaching the poorest and most vulnerable.

The overall government strategy has been towards ensuring macro-economic stability and creating an environment conducive to the private sector, while leaving it to market forces to develop industry and business for a more diversified economic growth (Masire, 2006). In the words of the IMF, 'Botswana has followed textbook macroeconomic advice on attracting investment inflows' (IMF, 2007:30). Employers have few contractual obligations towards the employee; there are (very low) minimum wages and limited social security requirements which may increase costs; and labour regulations are fairly restrictive towards the organisation and mobilisation of the salaried class.

Despite impressive growth records, economic growth in Botswana is without equity and broad-based transformation (Samatar, 1999; Hillbom, 2008). There have been no structural changes in the patterns of production which would otherwise drive economic transformation. Instead, outside the diamond sector, the economic sectors are characterised by limited technological innovation and low productivity. Economic exports are overwhelmingly dominated by the labourextensive diamond sector while industrial exports add to less than $10 \%$ of total exports (Hillbom, 2008).

The agricultural sector most clearly reveals a society with little structural transformation. Agricultural exports account for a mere $2 \%$ of total exports; even so, however, roughly $21 \%$ of the labour force is still employed in this sector (CSO, 2004:125). The livestock sector dominates agricultural production, but there has been little progress in technological innovation or value-added activities. One significant development in the rural sector has been the increasing exclusion of many rural families from agricultural production. Over the decades, crop production for food has decreased, meaning that many families are no longer self-sufficient. Instead, the rural poor seek to obtain casual labour at stipulated salary levels even lower than minimum wages for other income groups (Wikan, 2004; Republic of Botswana, 2008).

Even though formal sector employment has increased over the years, only just above half of all economically active persons are in paid employment, with formal unemployment levels persisting above 20\% (CSO, 2004:41). Botswana has then been unsuccessful in ensuring economic transformation which offers meaningful and broad-based employment opportunities. In fact, many people in rural and urban areas alike subsist on considerably low salary levels - a monthly full-time minimum wage is about P500-P600 (about US\$75-90, April 2008) while the food basket in most urban areas is suggested to be well over P2000 (FES, 2008:14; Republic of Botswana, 2008).

Generally, there is little social security for many Batswana. There is no regulatory framework to ensure compensation at times of unemployment. Sickness and maternity leave and work injury regulations are minimal and likely to depend largely on one's position and place of employment (SSA, 2009:38-39). Needless to say, anyone in informal or temporary employment has few rights when unable to work.

There are a number of social assistance programmes in place - some specifically target the needy, including public works programmes and the destitute policy; other policies, such as pension and school feeding schemes, have a broader reach (Seleka et al., 2007). Even so, social transfers are of little relevance to most Batswana. The old age pension is insufficient to cover monthly costs and require that elderly find additional resources elsewhere in order to ensure a reasonable income security (Wikan, 2004). The destitute policy only reaches a small segment of the population; with 38,074 registered destitute in 2005 (Ntseane \& Solo, 2007:89-91), no more than about $2 \%$ of the population receive destitute allowances. Public works programmes tends to have a broader reach but is temporary and, as with feeding programmes, mainly ensures that people stay alive.

\subsection{Purposeful economic transformation and social protection in Mauritius}

At independence in 1968 Mauritius was, like Botswana, an extreme form of a mono-crop economy with high reliance on sugar exports and few other developed economic sectors. Yet the government 
pursued economic transformation to create employment and gradual expansion of social security programmes.

From early on the government followed a two-pronged industrial strategy. On the one hand, the government supported import-substituting industries (ISI) which catered for the small domestic market, and on the other hand, the government endorsed export-processing industries for the foreign markets. The export-processing zone (EPZ) promoted low-wage industries with few labour law requirements and provided preferential access to EU and USA markets. Government employees, ISI workers, and agricultural labourers (all male dominated) enjoyed higher wages and benefits, whereas the EPZ primarily employed women whose earnings supplemented family incomes (Wellisz \& Saw, 1993:232-34; Bräutigam, 1999:147-52).

Despite economic difficulties in the 1980s and adherence to structural adjustment programmes, the Mauritian government was successful in following its full employment strategies without cutting social security. Trade liberalisation was gradual thereby allowing local industries to adjust, and though wage policies were geared towards enhancing export competitiveness, the lowest wage earners received greater wage increases than higher income groups thereby compressing wage differentials. The EPZ industry and the tourism sector grew rapidly, employment increased dramatically, and following the near exhaustion of labour reserves by the turn to the 1990s wage levels rose (Bowman, 1991:120-21; Wellisz \& Saw, 1993:248-50; Anker et al., 2001:19,29).

A consequences of the economic transformation is that income inequality declined during the 1980 s from a Gini coefficient of 0.5 to about 0.37 where it has stayed up to the 2000s (Bundoo, 2006). It is also suggestive of the different economic strategies in our two cases that Mauritius has a higher degree of income equity across different economic sectors than Botswana - the difference between the highest and lowest income group is twice as large in Botswana than in Mauritius (Appendix 2).

During the 2000s Mauritius lost guaranteed prices and market access for sugar and textiles and saw an increase in unemployment, consequently the government has pursued economic diversification towards ICT and offshore business services in order to ensure continued economic growth and employment creation (Bundoo, 2006). The recently introduced Employment Rights Act is suggestive of how the government seeks to balance social and economic strategies. The Act aims to improve worker flexibility by limiting the employees' rights while, at the same time, assisting in skills retraining and providing unemployment benefits to ensure social security in case of job loss (Government of Mauritius, 2008).

In fact, social security policies have throughout been an important element of the developmental strategies in Mauritius. Overall, social transfers constitute the second largest source of income in Mauritius with transfer income amounting to, on average, about $13 \%$ of total gross income (CSO, 2007). Unlike Botswana who spends between $2-3 \%$ of the government budget on social security, in Mauritius social security policies sit at about $20 \%$ of government expenditures (Ulriksen, 2010:175).

Already in the 1970s the government of Mauritius established an encompassing and generous pension scheme ensuring a large degree of income security across the board. Whereas Botswana also has a universal, non-contributory pension (from 1996), the provision of pension is generally more substantial and far-reaching in Mauritius. Not only is the basic pension in Mauritius larger (about the double of Botswana's), it is also paid out at age 60, compared to 65 in Botswana. Furthermore, pension in Mauritius is also available to disabled, widows, and orphans, while it purely refers to old age in Botswana. Finally, the pension scheme in Mauritius is complemented by a welldeveloped contributory scheme, which tops up pension for many retired people (Willmore, 2006; Seleka et al., 2007).

During the first decades after independence, sugar tax revenues, in the main, funded the expansion of social transfers and social services. Taxation was generally progressive, though few were except from paying tax (Wellisz \& Saw, 1993:239; Bräutigam, 2008:154-55). The broad-based contribution to broadly based social security policies is quite distinct from Botswana where mineral incomes have generally funded the limited social safety nets. 


\section{Comparing Botswana and Mauritius and lessons for South Africa}

The comparison of Botswana and Mauritius supports and further substantiates the findings of the statistical analysis. The divergent social outcomes in the two countries are largely explained by the extent of social security policies and how well the countries' growth adventures have been complemented by economic transformation. In Mauritius, development strategies have not been about the poor, but rather about creating economic transformation, employment and social security for the whole population. In Botswana, economic growth have been driving developmental strategies; poor people struggle to become part of a productive economy and the most vulnerable of them have come to rely on meagre social safety nets.

While this paper suggests that broad-based social policies and economic transformation decrease poverty and inequality; it is still an ambiguous issue how to advance economic transformation which increase employment opportunities without hampering economic growth. An equally critical question is how to ensure public commitment to social policy expansion and financing. Theoretically, it was suggested that political feedbacks frame policy development. In Mauritius social and economic policies have been forged by compromises of high-, middle- and lowincome groups, such that everyone benefits but also contributes. Additionally, while the generous social policies in Mauritius improve well-being, the ability to create meaningful employment and keep wage differentials relatively low has also contributed to reductions in poverty and inequality. Conversely, in Botswana, lack of economic transformation has caused a shortage of decent employment. There is arguably a split in Botswana between those that benefit from formal employment with private social insurance schemes, and the rest who struggle in low-paid jobs where the most vulnerable receive some minimal social protection. The better-off and politically influential groups benefit little from social welfare, and hence they may be unwilling to bear the costs of potential social policy expansion (Ulriksen, 2010).

From an economic strategy perspective, South Africa appear more like Botswana as the political objectives have generally been to achieve economic growth and as there is a split between the modern economy and the largely rural areas where economically meaningful livelihoods are few. From a social policy perspective, South Africa may be closer to Mauritius. Certainly, South Africa does have quite extensive social protection policies for the region with about one-quarter of all South Africans receiving monthly cash transfers (Lund, 2009:300). However, unlike Mauritius, social security policies are generally targeted and therefore exclude not only middle-class, but surely also many with lower incomes. Moreover, with little more than 5 million South African tax payers (DNT, 2008), there is a relatively small resource base from where to finance social policies. As such there appear to be another split - between beneficiaries and contributors of social policies.

Keeping in mind that structural inequality built over three centuries are not easily overcome, South Africa's challenges of poverty and inequality may be confronted by asking how to bridge these social and economic divides. Asking not just how the poor can benefit, but rather how all income groups of some (occasional) income insecurity may benefit as well as contribute. For instance, a broadening of the tax base could offer an opportunity to introduce social security policies benefiting more widely. Equally, if labour flexibility is necessary to improve market adaptability and employment creation, such threats to labour rights may be compromised against better social security and/or decent salary levels. South Africa must find its own solutions, but experiences from other developing countries certainly offer the opportunity to reflect on the social consequences of different social and economic policy frameworks.

\section{References}

Adésínà, J, 2010. Rethinking the Social Protection Paradigm: Social Policy in Africa's Development. Commission Background Paper for the European Report on Development 2010. Florence: European University Institute

Anker, R, Paratian, R \& Torres, R, 2001. Mauritius. Geneva: International Labour Organization

Barrientos, A, 2010. Social Protection and Poverty. UNRISD: Social Policy and Devleopment Programme, Paper Number 42 
Besley, T \& Cord, L (Eds) (2007). Delivering on the Promise of Pro-Poor Growth: Insights and Lessons from Country Experiences. Washington DC: Palgrave Macmillan / World Bank

Birdsall, N, 2010. The (Indispensable) Middle Class in Developing Countries; or, The Rich and the Rest, Not the Poor and the Rest. Center for Global Development. Working Paper 207

Bonoli, G, 1997. Classifying Welfare States: a Two-dimension Approach. Journal of Social Policy, 26(3), 351-72

Bowman, L, 1991. Mauritius: Democracy and Development in the Indian Ocean. Boulder: Westview Press

Bräutigam, D, 1999. The 'Mauritius Miracle': Democracy, Institutions, and Economic Policy. In Joseph, R (Ed.), State, Conflict, and Democracy in Africa. Boulder: Lynne Rienner Publishers

Bräutigam, D, 2008. Contingent capacity: export taxation and state-building in Mauritius. In Bräutigam, D, Fjeldstad, O \& Moore, M (Eds), Taxation and State-Building in Developing Countries. Cambridge: Cambridge University Press

Bundoo, S, 2006. Financial and Trade Reforms and Impact on Poverty and Income Inequality: The Case of Mauritius. In Cornia, G (Ed.), Pro-Poor Macroeconomics: Potential and Limitations. Basingstoke: Palgrave

Cichon, M \& Scholz, W, 2009. Social Security, Social Impact and Economic Performance: a Farewell to Three Famous Myths. In Townsend, P (Ed.), Building Decent Societies. Hampshire: Palgrave Macmillan

CSO (Central Statistics Office) 2004. Household Income and Expenditure Survey 2002/03. Gaborone: Government Printer

CSO (Central Statistics Office) 2007. Household Budget Survey 2006/2007 - Main Results. Port Louis. http://www.gov.mu/portal/site/cso Accessed 17 January 2008

Deacon, B, 2010. From the global politics of poverty alleviation to the global politics of welfare state rebuilding. CROP Poverty Brief, June 2010

DNT (Department: National Treasury) 2008. 2008 Tax Statistics. National Treasury \& South African Revenue Service, Pretoria

Ellis, F, Devereux, S \& White, P, 2009. Social Protection in Africa. Cheltenham: Edward Elgar Publishing

Esping-Andersen, G, 1990. The Three Worlds of Welfare Capitalism. Cambridge: Polity Press

FES (Friedrich Ebert Stiftung) 2008. Trade Unions in Botswana: Country Report 2008. Gaborone: Friedrich Ebert Stiftung

Gelbach, JB \& Pritchett, LH, 2000. Indicator targeting in a political economy: Leakier can be better. Journal of Economic Policy Reform, 4(2), 113-45

Government of Mauritius, 2008. The Employment Rights Act 2008. Port Louis http://www.gov.mu/portal/site/laboursite/menuitem.cdc4d8aba512ae8967b4dc46a0208a0c/ Accessed 25 August 2010

Hickey, S, Sabates-Wheeler, R, Guenther, G \& Macauslan, I, 2008. Promoting SP \& ST: DFID the Politics of Influencing. DFID Evaluation Report, London: DFID 
Hillbom, E, 2008. Diamonds or development? A structural assessment of Botswana's forty years of success. Journal of Modern African Studies, 46(2), 191-214

ILO \& WHO, 2009. The Social Protection Floor. A joint Crisis Initiative of the UN Chief Executives Board for Co-ordination on the Social Protection Floor, Geneva, October 2009

IMF, 2007. Botswana: Selected Issues and Statistical Appendix. IMF Country Report, No. 07/228, Washington D.C.: International Monetary Fund

Korpi, W \& Palme, J, 1998. The Paradox of Redistribution and Strategies of Equality: Welfare State Institutions, Inequality, and Poverty in the Western Countries. American Sociological Review 63(5), 661-687

Loayza, N \& Raddatx, C, 2010. The composition of growth matters for poverty alleviation. Journal of Development Economics, 93(1), 137-51

Lund, F, 2009. Welfare, Development and Growth: Lessons from South Africa. In Townsend, P (Ed.), Building Decent Societies. Hampshire: Palgrave Macmillan

Masire, Q, 2006. Very Brave or Very Foolish? Memoirs of an African Democrat, Gaborone: Macmillan Botswana Publishing

Mkandawire T. (Ed.) 2004. Social policy in a development context. New York: Palgrave Macmillan

Norton, A, Conway, T \& Foster, M, 2002. Social Protection: Defining the Field of Action and Policy. Development Policy Review 20(5), 541-567

Ntseane, D \& Kholisani S, 2007. Social Security and Social Protection in Botswana, Gaborone: Bay Publishing

Ravallion, M, 2008. Bailing out the World's Poorest. The World Bank, Policy Research Working Paper 4763

Republic of Botswana, 2008. Government Gazette: Extraordinary, Vol. XLVI, No.20, 31 $1^{\text {st }}$ March 2008. Government Printer, Gaborone

Samatar, A, 1999. An African Miracle: State and Class Leadership and Colonial Legacy in Botswana Development. Portsmouth: Heinemann

Samson, M, 2009. The Impact of Social Transfers on Growth, Development, Poverty and Inequality in Developing Countries. In Townsend, P (Ed.), Building Decent Societies. Hampshire: Palgrave Macmillan

Seleka, T, Siphambe, H, Ntseane, D, Mbere, N, Kerapeletswe, C \& Sharp, C, 2007. Social Safety Nets in Botswana: Administration, Targeting and Sustainability. Gaborone: Botswana Institute for Development Policy Analysis

SSA (Social Security Administration), 2009. Social Security Programs Throughout the World: Africa 2009. Washington: SSA Publication No. 13-11803

Ulriksen, M, 2010. Politics, Policy, and Poverty in Botswana, Mauritius, and other developing countries. PhD Thesis, Aarhus University, Denmark

UNRISD, 2010. Combating Poverty and Inequality. UNRISD Research and Policy Brief, May 2010

Wellisz, S \& Saw, PLS (1993). Mauritius. In Findlay, R \& Wellisz, S (Eds), Five Small Open Economies. Oxford: Oxford University Press 
Wikan, G, 2004. The level of living in rural Botswana re-studied. Norwegian Journal of Geography, 58(1), $1-10$

Willmore, L, 2006. Universal age pensions in developing countries: The example of Mauritius. International Social Security Review, 59(4), 67-89

World Bank, 2001. World Development Report 2000/01: Attacking Poverty. Oxford: Oxford University Press 
Appendix 1: Explanation of variables for statistical analysis

\begin{tabular}{|c|c|c|c|}
\hline Variable & Explanation & Year & Source \\
\hline Countries & $\begin{array}{l}\text { All developing countries (middle and low income) with HPI } \\
\text { value (except Palestine) }\end{array}$ & & $\begin{array}{l}\text { World Bank list of economies (July } \\
\text { 2007) }\end{array}$ \\
\hline $\begin{array}{l}\text { Government } \\
\text { effectiveness }\end{array}$ & $\begin{array}{l}\text { Government effectiveness; an index that measures the } \\
\text { quality of public services, the quality of the civil service and } \\
\text { the degree of its independence from political pressure, the } \\
\text { quality of policy formulation and implementation, and the } \\
\text { credibility of government's commitment to such policies. This } \\
\text { index has scores from }-2.5 \text { to } 2.5 \text { where higher scores } \\
\text { correspond to better government effectiveness }\end{array}$ & 2004 & $\begin{array}{l}\text { Kaufman et al. 2007. Governance } \\
\text { Matter VI. Washington: World Bank, } \\
\text { Table C3 + p.3 }\end{array}$ \\
\hline Democracy & $\begin{array}{l}\text { Polity IV. The Polity scheme consists of six component } \\
\text { measures that record key qualities of executive recruitment, } \\
\text { constraints on executive authority, and political competition. } \\
\text { Score from }-10 \text { to } 10\end{array}$ & Most recent & $\begin{array}{l}\text { Downloaded Polity IV Project } \\
\text { homepage: } \\
\text { http://www.systemicpeace.org } \\
\text { /polity/polity4.htm }\end{array}$ \\
\hline HIV/AIDS & HIV prevalence as percentage of aged $15-49$ & 2006 & $\begin{array}{l}\text { UNDP 2007. Human Development } \\
\text { Report 2007/08. New York: } \\
\text { Palgrave Macmillan, Table } 9\end{array}$ \\
\hline Unemployment & Unemployment rate as a percentage of total labour force & $1996-2005$ & $\begin{array}{l}\text { UNDP 2007, Table 21; supple- } \\
\text { mented by data from the World } \\
\text { Bank website May } 2008\end{array}$ \\
\hline GDP per capita & GDP per capita PPP US $\$$ & 2005 & UNDP 2007, Table 1 \\
\hline $\begin{array}{l}\text { Economic } \\
\text { modernisation }\end{array}$ & $\begin{array}{l}\text { Percentage of employed work force not working in the } \\
\text { agricultural sector; i.e. value turned: } 100 \text { minus } \% \text { employed } \\
\text { in agriculture }\end{array}$ & $1996-2005$ & UNDP 2007, Table 21 \\
\hline Social expenditures & $\begin{array}{l}\text { Social security expenditures as a percentage of GDP; } \\
\text { covers expenditures on pensions, health care, employment } \\
\text { injury, sickness, family housing and social assistance } \\
\text { benefits in cash and in kind, incl. also administrative } \\
\text { expenses }\end{array}$ & $1996(1990)$ & $\begin{array}{l}\text { ILO 2000. World Labour Report, } \\
\text { Geneva, International Labour } \\
\text { Office: table } 14+\text { pp.320-21; } \\
\text { supplemented with data from } \\
\text { website: } h \text { http://www-ilo-mirror. } \\
\text { cornell.edu/public/english/protection }\end{array}$ \\
\hline
\end{tabular}




\begin{tabular}{|l|l|l|l|}
\hline Social coverage & \multicolumn{1}{|c|}{} & /socfas/research/stat/table14 \\
& $\begin{array}{l}\text { The 'social policy protection index' - covers the scope of } \\
\text { social insurance coverage (on old-age, sickness, disability, } \\
\text { and unemployment) and the redistribution that these } \\
\text { particular social policies undertake across occupations; the } \\
\text { higher the score the more the policies cover across groups }\end{array}$ & 2005 & $\begin{array}{l}\text { Kindly made available by Isabela } \\
\text { Mares; ref also Mares 2005. Social } \\
\text { Protection Around the World: } \\
\text { External Insecurity, State Capacity, } \\
\text { and Domestic Political Cleavages. } \\
\text { Comparative Political Studies, } \\
38(6), 623-51\end{array}$ \\
\hline $\begin{array}{l}\text { Social security } \\
\text { policies }\end{array}$ & $\begin{array}{l}\text { Social expenditures + social coverage; calculated so that } \\
\text { values goes from 0-100 }\end{array}$ & & UNDP 2007, Table 3, 355-57 \\
\hline $\begin{array}{l}\text { Human Index (HPI) } \\
\text { Poverty }\end{array}$ & $\begin{array}{l}\text { Human poverty index; measures the proportion of people } \\
\text { below a threshold level in basic dimensions of human } \\
\text { development - living a long and healthy life (probability at } \\
\text { birth of not surviving to age 40), having access to education } \\
\text { (\% of adults who are illiterate), and a decent standard of } \\
\text { living (\% not having sustainable access to water and \% of } \\
\text { children below age 5 who are underweight). Values are from } \\
0-100, \text { higher scores indicate greater incidence of poverty }\end{array}$ & $1995-2005$ & \\
\hline
\end{tabular}


Appendix 2: Monthly wages per sector in Botswana and Mauritius, 2005

\begin{tabular}{|lrrrr|}
\hline & \multicolumn{2}{c}{ Botswana } & \multicolumn{2}{c|}{ Mauritius } \\
\hline \hline Economic activity & Pula & US\$* & Rupees & US $\$^{* *}$ \\
\hline \hline Agriculture, hunting, forestry & 697 & 137 & 9824 & 332 \\
Mining, quarrying & 4518 & 886 & 5588 & 189 \\
Manufacturing & 1219 & 239 & 7798 & 263 \\
Electricity, gas, water supply & 6124 & 1201 & 19457 & 657 \\
Construction & 1138 & 223 & 12042 & 407 \\
Wholesale and retail trade & 1725 & 338 & 12772 & 431 \\
Hotel \& restaurants & 1015 & 199 & 9881 & 334 \\
Transport, storage, communication & 3585 & 703 & 15982 & 540 \\
Financial intermediation & 6461 & 1267 & 21478 & 726 \\
Real estate, renting \& business activities & 2294 & 450 & 12822 & 433 \\
Public administration, defence, compulsory & & & & \\
social security ${ }^{* *}$ & 3489 & 684 & 15066 & 509 \\
Education & 5010 & 982 & 15008 & 507 \\
Health \& social work & 2328 & 456 & 16628 & 562 \\
Other community, social \& personal activities & 2629 & 515 & 11427 & 386 \\
\hline \hline Average & 2141 & 420 & 12067 & 408 \\
Difference between highest and lowest & & & & 537 \\
income groups & 5764 & 1130 & 15890 & \\
\hline Soure: & & & & \\
\hline
\end{tabular}

Source: http://laborsta.ilo.org, last accessed 26 August 2010

* Average exchange rate for 2005: 5.1 BWP to 1 USD

** Average exchange rate for 2005: 29.6 MUR to 1 USD

*** For Botswana: Average monthly cash earnings for central government (ref. Bank of Botswana, 2007) 